\title{
RYNEK UBEZPIECZEŃ KREDYTU W POLSCE - OCENA TENDENCJI OGÓLNYCH
}

\author{
Maria Gorczyńska \\ Katedra Finansów Przedsiębiorstw i Ubezpieczeń Gospodarczych \\ Uniwersytet Ekonomiczny w Katowicach
}

\begin{abstract}
Abstrakt. Ubezpieczenia kredytu stanowią jedną z metod ochrony przed skutkami ryzyka niewypłacalności dłużników. Celem artykułu jest ocena tendencji ogólnych zachodzących na rynku ubezpieczeń kredytu w Polsce w latach 2004-2015. Dostępne dane dotyczące rynku ubezpieczeń w Polsce poddano analizie, wyodrębniając elementy odnoszące się do podaży ubezpieczeń kredytu, popytu na te ubezpieczenia, a także równowagi rynkowej. Badania wykazały, że dostępność ubezpieczeń kredytu kształtowała się na podobnym poziomie w rozpatrywanym okresie, a główną grupą ich nabywców pozostały przedsiębiorstwa. Począwszy od 2009 roku wyraźnie zmienił się poziom szkodowości ubezpieczeń kredytu.
\end{abstract}

Słowa kluczowe: ubezpieczenie kredytu, rynek ubezpieczeń, przedsiębiorstwa

\section{WSTĘP}

Działalność gospodarcza w warunkach gospodarki rynkowej wiąże się z koniecznością podejmowania decyzji, które muszą być dostosowane do zasad funkcjonowania wolnego rynku. Ciągła zmienność warunków rynkowych zewnętrznych i wewnętrznych wymusza podejmowanie działań obarczonych różnym stopieniem ryzyka. Zawieranie kontraktów (umów), które skutkują powstaniem zobowiązania dłużnika, co do zapłacenia określonej kwoty pieniężnej w ściśle określonym terminie, rodzą określone ryzyko kredytowe. Instrumentem neutralizującym skutki wystąpienia takiego ryzyka jest ubezpieczenie kredytu. Ubezpieczenie to staje się instrumentem ochrony przed ryzykiem, że dłużnik nie spłaci długu lub zapłaci dług w terminie późniejszym. Zakłady ubezpieczeń na podstawie umo- 
wy ubezpieczenia kredytu zobowiązują się więc do pokrycia strat majątkowych kredytodawcy, wywołanych niedotrzymaniem warunków umowy kredytu przez kredytobiorcę [Handschke 2001].

Celem niniejszego artykułu jest ocena zmian zachodzących na polskim rynku ubezpieczeń kredytu w okresie 2004-2015. Ocenę tę wykonano na podstawie danych publikowanych przez Główny Urząd Statystyczny (dla lat 2004-2014) oraz przez Komisję Nadzoru Finansowego (dla 2015 roku).

W pierwszej części artykułu omówiono metodykę i zakres badań zawartych w artykule, odwołując się także do wyników przeprowadzonych dotąd badań w odniesieniu do sytuacji w Polsce. $W$ drugiej części zaprezentowano charakterystykę ubezpieczeń kredytu. W części trzeciej zaprezentowano i omówiono otrzymane wyniki, z których sformułowano wnioski końcowe.

\section{METODYKA I ZAKRES BADAŃ}

Badania zarówno jakościowe, jak i ilościowe dotyczące polskiego rynku ubezpieczeń kredytu często koncentrują się na jednym, wybranym produkcie, którym są ubezpieczenia kredytu kupieckiego $w$ krajowym i zagranicznym obrocie. Badania te wskazują między innymi na dynamiczny rozwój ubezpieczeń kredytu kupieckiego, duży udział tej grupy ubezpieczeń w grupie ubezpieczeń kredytu (por. [Bacella 2015]), a także na duże uzależnienie wykorzystywania tej formy zabezpieczenia ryzyka przez przedsiębiorstwa od sytuacji makroekonomicznej w gospodarce (por. [Lisowski 2009, Lisowski 2010, Bacella 2015]).

W niniejszym artykule analizie poddano rynek ubezpieczeń kredytu jako całość, ze szczególnym uwzględnieniem roli przedsiębiorstw jako podmiotów nabywających te ubezpieczenia. Dane dotyczące funkcjonowania rynku ubezpieczeń w Polsce poddane analizie publikowane są w ujęciu zbiorczym przez Główny Urząd Statystyczny, począwszy od danych za 2004 rok [GUS 2015]. Zbiór tych danych obejmuje zatem informacje o ponad 10-letnim okresie funkcjonowania polskiego rynku ubezpieczeniowego. Dane skatalogowane są według grup ubezpieczeniowych, co pozwala wyselekcjonować informacje dotyczące ubezpieczeń kredytu (grupy 14). Dla ukazania najbardziej aktualnego stanu badanych problemów tam, gdzie było to możliwe, uwzględniono również dane za 2015 rok, pochodzące z publikacji Komisji Nadzoru Finansowego ${ }^{1}$ [KNF 2015]. Dostępne dane umożliwiają

\footnotetext{
${ }^{1}$ Dane GUS za rok ubiegły (tutaj 2015 rok) udostępniane zostają pod koniec kolejnego roku kalendarzowego (tutaj 2016). Z tego względu, dla ukazania jak najaktualniejszych danych w obrębie rozważanych problemów, uwzględniono dane dotyczące 2015 roku publikowane przez Komisję Nadzoru Finansowego (publikowane w ramach biuletynów rocznych).
} 
także poszerzenie analizy o kontekst konkretnych grup nabywców ubezpieczeń. W odniesieniu do rozważanego tu problemu szczególnie istotne są informacje uwzględniające aktywność przedsiębiorstw na rynku ubezpieczeń kredytu.

Projektując badania własne, zwrócono uwagę na możliwość ich prezentacji $\mathrm{w}$ trzech płaszczyznach odnoszących się do problematyki funkcjonowania rynku, a mianowicie wybranych elementów określających obszary:

- podaży ubezpieczeń kredytu,

- popytu na ubezpieczenia kredytu (w sektorze przedsiębiorstw),

- równowagi rynkowej.

W aspekcie podaży ubezpieczeń kredytu analizie poddano ofertę ubezpieczeń kredytu w zakresie liczby zakładów ubezpieczeń posiadających zezwolenie na sprzedaż ubezpieczeń grupy $14^{2}$. Warto zaznaczyć, że w odniesieniu do minimum tej grupy ubezpieczeń prawo formułuje zwiększone wymogi kapitałowe wobec ubezpieczycieli. W obszarze popytu na ubezpieczenia kredytu uwagę skoncentrowano na aktywności przedsiębiorstw, które są dominującą grupą nabywców tych ubezpieczeń (biorąc pod uwagę wolumen składki przypisanej brutto).

W obszarze równowagi rynkowej analizie poddano prosty wskaźnik szkodowości $(L R)$, relacjonujący dla danego okresu wysokość składki przypisanej brutto ubezpieczeń danej grupy $(P I)$ do wartości wypłaconych odszkodowań i świadczeń w danej grupie ubezpieczeń $(C I)$ :

$$
L R=P I / C I
$$

Wskaźnik ten pozwala odnieść się w pewnym sensie do efektywności zastosowania ubezpieczeń kredytu, gdyż może stanowić podstawę oceny opłacalności tego ubezpieczenia z perspektywy zarówno przedsiębiorstw (jako elementu strony popytowej), jak i ubezpieczycieli (jako elementu strony podażowej).

\section{CHARAKTERYSTYKA UBEZPIECZEŃ KREDYTU}

Przedmiotem ubezpieczenia kredytu stają się wierzytelności pieniężne powstałe w wyniku zawierania umów, które skutkują zobowiązaniem do zapłaty środków pieniężnych przez dłużnika w określonym terminie [Gorczyńska

\footnotetext{
${ }^{2}$ Uwzględniona w niniejszych badaniach kwestia oferty ubezpieczycieli w zakresie ubezpieczeń kredytu ma oczywiście charakter bardzo ogólny (uwzględnia jedynie otrzymanie zezwolenia na działalność w grupie 14 ubezpieczeń). Realną ocenę oferty ubezpieczeń kredytu można przeprowadzić dopiero na podstawie analizy produktów oferowanych przez poszczególnych ubezpieczycieli. W niniejszej prezentacji problem ten pominięto, gdyż materiał badawczy jest zbyt rozległy, aby zaprezentować całość wyników badań spełniając wymogi dotyczące obszerności artykułu.
} 
i Wieczorek-Kosmala 2013]. Umowa ubezpieczenia kredytu może zostać zawarta $\mathrm{z}$ wierzycielem lub dłużnikiem. $\mathrm{W}$ pierwszym wariancie interes ubezpieczeniowy jest po stronie wierzyciela, ponieważ to on ponosi ryzyko kredytowania. Wierzyciel jest wówczas zarówno ubezpieczającym, jak i ubezpieczonym, co w konsekwencji oznacza konieczność opłacenia składki ubezpieczeniowej. $\mathrm{W}$ drugim wariancie ubezpieczenie jest zawierane na rzecz osoby trzeciej [Michalik i Seliga 2003], tj. umowa ubezpieczenia zostaje zawarta między ubezpieczycielem a dłużnikiem, który staje się ubezpieczający i dokonuje zapłaty składki ubezpieczeniowej. Wierzyciel zaś staje się ubezpieczonym, na rzecz którego zostanie wypłacone odszkodowanie.

Ubezpieczenie ryzyka kredytowego powstaje w różnych okolicznościach, stąd też występują określone rodzaje ubezpieczeń kredytu. Istnieje wiele kryteriów, według których dokonuje się ich klasyfikacji, takie jak: rodzaj kredytu, forma polisy, długość trwania kredytu itp. [Lisowski 2010]. Najpowszechniej jednak omawiane w literaturze przedmiotu jest ubezpieczenie kredytu kupieckiego, co wynika z szerokiego wykorzystywania tej formy zabezpieczenia ryzyka kredytowego $\mathrm{w}$ praktyce gospodarczej. Pozostałe formy ubezpieczeń kredytu to ubezpieczenie kredytu bankowego, a także ubezpieczenie należności leasingowych czy należności factoringowych [Kukiełka i Poniewierka 2003].

Zakłady ubezpieczeń na polskim rynku ubezpieczeń w swojej ofercie mają wszystkie wyżej wymienione formy ubezpieczeń kredytu. Zakłady ubezpieczeń wychodzą na przeciw zapotrzebowaniu rynku i mają szeroką ofertę ubezpieczeń kredytu kupieckiego zarówno w obrocie krajowym, jak i zagranicznym dla przedsiębiorstw, których podstawą działalności jest korzystanie z odroczonych terminów płatności. Przedmiotem ubezpieczenia kredytu kupieckiego są bezsporne należności z tytułu udzielonych kredytów handlowych, które powstały w wyniku sprzedaży dóbr i usług zgodnie $\mathrm{z}$ wystawionymi fakturami w okresie ubezpieczenia i nie zostały zapłacone $w$ terminach i kwotach określonych $w$ fakturach w ramach przyznanych przez ubezpieczyciela limitów kredytowych, stanowiących górne granice odpowiedzialności zakładów ubezpieczeń [Strupczewski 2013]. Ochrona ta dotyczy tylko tych należności, które nie zostaną zapłacone z powodu tzw. trwałej niezdolności dłużnika. Ubezpieczeniem tym objęte zostaje ryzyko jednego kontrahenta lub grupy kontrahentów, a także całego obrotu z warunkiem odroczonych terminów płatności. Zakłady ubezpieczeń w celu ograniczenia ryzyka negatywnej selekcji oferują korzystniejsze warunki ubezpieczenia dla umów zawartych dla grup kredytobiorców czy też w przypadku ubezpieczenia całego obrotu. Składki ubezpieczeniowe są zróżnicowane i generalnie zależą od: zasad rozliczeń przyjętych przez zakład ubezpieczeń, liczby i rodzajów dłużników, branży, w jakiej działa, oraz pozostałych czynników dotyczącego tego typu ubezpieczenia. Podstawowym wyłączeniem odpowiedzialności zakładów ubez- 
pieczeń w tym rodzaju ubezpieczenia jest krótkotrwała utrata płynności dłużnika przedsiębiorstwa. Zakłady ubezpieczeń oferują przy zawarciu umowy ubezpieczenia kredytu kupieckiego także usługi dodatkowe, np. ocenę ryzyka kredytowego kontrahenta, któremu udzielany będzie odroczony termin płatności przez przedsiębiorstwo. W przypadku ubezpieczenia kredytu kupieckiego w obrocie zagranicznym zakłady ubezpieczeń oferują przejęcie ryzyka handlowego. Oferowane ubezpieczenie ryzyka handlowego głównie obejmuje: niewypłacalność prawnie stwierdzoną (ang. declared insolvency), niewypłacalność domniemaną (ang. persumed insolvency) oraz nieprzyjęcie przez importera dostarczonych zgodnie $\mathrm{z}$ warunkami umowy towarów lub usług, ale co nie wynika $\mathrm{z}$ winy eksportera [Bednarczyk 2000]. W przypadku kontraktu eksportowego przedsiębiorstwa są zainteresowane także zabezpieczeniem się przed ryzykiem niehandlowym, które pozostaje poza stosunkiem kredytowym i ma ono cechy tzw. siły wyższej (ryzyko polityczne, katastrofalne, przewlekłej zwłoki w zapłacie publicznego kontrahenta) [Olkiewicz 2010]. Zakłady ubezpieczeń w przypadku ryzyka niehandlowego stosują wyłączenie jego spod ochrony ubezpieczeniowej. Tą formę ubezpieczeń na polskim rynku wypełnia oferta instytucji stworzonej w celu wspierania eksportu - Korporacja Ubezpieczeń Kredytów Eksportowych (KUKE), która ma możliwość ubezpieczenia kontraktów ubezpieczeniowych i kredytów eksportowych według ustawy z 1994 roku o gwarantowanych ubezpieczeniach kontraktów eksportowych. Ubezpieczenie kredytu kupieckiego stanowi istotny element w procesie zarządzania wierzytelnościami przedsiębiorstwa, a poziom jego wykorzystywania przez przedsiębiorstwa jest uzależniony od wielu czynników zarówno makro- jak i mikroekonomicznych [Pawłowska-Kłąb 2006].

Kolejnym rodzajem ubezpieczenia kredytu jest ubezpieczenie kredytu bankowego. W zależności od rodzaju kredytu zakłady ubezpieczeń oferują ubezpieczenie kredytu obrotowego, hipotecznego, inwestycyjnego, konsumpcyjnego itd. [Znaniecka i in. 2014]. Standardowa oferta obejmuje przejęcie niewypłacalności dłużnika na zakład ubezpieczeń, ustalając górną granicę odpowiedzialności zakładu równą sumie rat kredytu wraz z odsetkami. Wysokość składki jest zróżnicowana i zależy przede wszystkim od sumy ubezpieczenia, długości terminu spłaty kredytu, rodzaju zabezpieczeń kredytu oraz standingu kredytobiorcy. Ta forma ubezpieczeń kredytu najczęściej jest skierowana wprost do insty tucji bankowych. Nieliczne zakłady ubezpieczeń przedstawiają możliwość ubezpieczenia kredytu przez kredytobiorcę - przedsiębiorstwo, które w ten sposób chce zabezpieczyć się przed własną niewypłacalnością w stosunku do swojego kredytodawcy.

Zakłady ubezpieczeń w grupie ubezpieczeń kredytu oferują także ubezpieczenie należności factoringowych, które przede wszystkim skierowane są do instytucji factoringowej, która zawiera z przedsiębiorstwem umowę o usługę factoringu bez prawa regresu. Na rynku można także znaleźć ofertę ubezpieczeń należności factoringowych skierowaną do przedsiębiorstw, które zawierają umowę o usługę 
factoringu z prawem regresu [Michalik i Seliga 2003]. Gdy ubezpieczenie jest zawierane $\mathrm{z}$ faktorem, stanowi zabezpieczenie dla faktora, $\mathrm{w}$ sytuacji gdy nie otrzyma on zapłaty od dłużnika. Z kolei gdy oferta jest skierowana do przedsiębiorstwa korzystającego z usługi factoringowej (faktoranta), ubezpieczenie stanowi możliwość odzyskania należności od dłużnika, gdy ten nie ureguluje długu faktorowi, a należność wraca do przedsiębiorstwa. Wyłączenia w tym rodzaju ubezpieczenia to głównie sytuacje gdy: faktorant niewłaściwie wywiązał się z umowy ze swoimi kontrahentami oraz faktorant nie nabył weksla własnego in blanco od dłużnika. Wysokość składki jest zróżnicowana i zależy głównie od charakteru należności przyjmowanych przez faktora oraz rodzaju factoringu. Rynek ubezpieczeń kredytu odpowiedział także na zapotrzebowanie w zakresie ubezpieczenia należności leasingowych. Ten rodzaj ubezpieczenia obejmuje należności przysługujące leasingodawcy. Najczęściej ubezpieczenia te oferowane są w postaci umowy generalnej [Kukiełka i Poniewierka 2003]. Przedmiotem ubezpieczenia może być całość należności leasingowej lub jej część. Stawki ubezpieczenia są zróżnicowane i zależne od wysokości pierwszej wpłaty leasingobiorcy, jego wiarygodności, warunków, na których została zawarta umowa leasingowa, i portfela leasingodawcy. W ofercie zakładów ubezpieczeń można także znaleźć ofertę dla leasingobiorcy, który przez zawarcie umowy ubezpieczenia chce przenieść na instytucję ubezpieczeniową ryzyko braku zapłaty czynszów leasingowych.

Ofertę produktową ubezpieczeń kredytu zakładów ubezpieczeń można uznać za zestandaryzowaną co do przedmiotu ubezpieczenia, jak i warunków ogólnych. Różnice można zaobserwować $\mathrm{w}$ warunkach szczegółowych oraz w wysokości składki ubezpieczeniowej. Uogólniając, oferta zakładów ubezpieczeń odpowiada na zapotrzebowanie produktów zabezpieczających ryzyko wynikające z zawierania umów o charakterze kredytowym przez podmioty na rynku.

\section{WYNIKI BADAŃ I DYSKUSJA}

Liczba zakładów ubezpieczeń działu II w analizowanym okresie zmniejszała się, jednak liczba ubezpieczycieli oferujących ubezpieczenia grupy 14 pozostawała na relatywnie stałym poziomie (rysunek 1). Ogólnie można zatem stwierdzić, że na przestrzeni analizowanych lat ubezpieczenia kredytu były dostępne, a liczba oferujących je zakładów ubezpieczeń gwarantowała zachowanie konkurencji rynkowej. Warto zaznaczyć, iż wśród oferentów ubezpieczeń znajduje się szczególny zakład ubezpieczeń, skupiający się na kredytach eksportowych - KUKE S.A. Korporacja KUKE S.A. oferuje swoim klientom, jak już wcześniej wspomniano, ubezpieczenie kredytu eksportowego i kontraktów w obrocie międzynarodowym na zlecenie Skarbu Państwa, ale także oferuje komercyjne ubezpieczenia kredytu kupieckiego w obrocie krajowym (szerzej zob. np. [Konat i in. 2011]). 


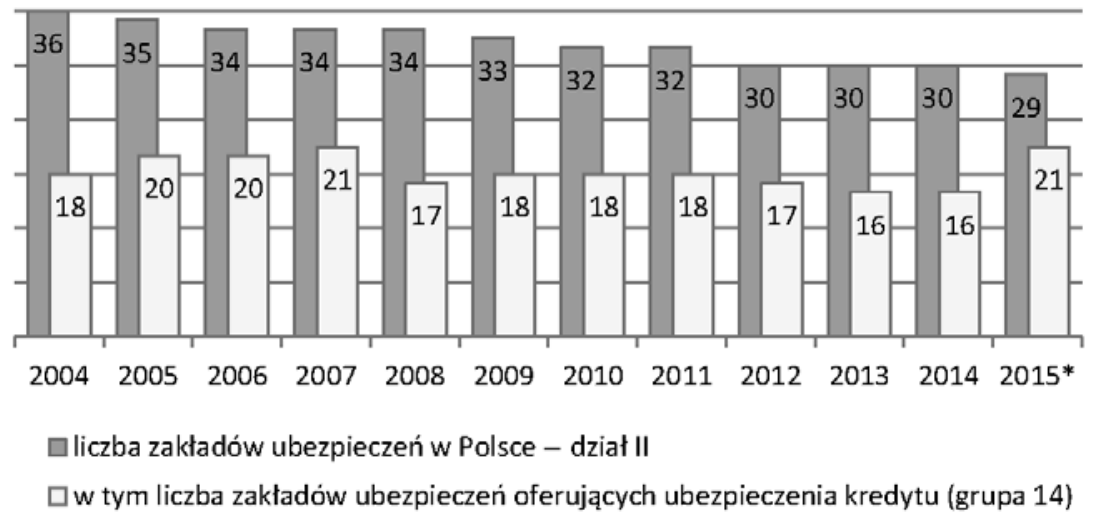

* Dane za lata 2004-2014 pochodzq z publikacji GUS, dane za 2015 rok z publikacji KNF.

RYSUNEK 1. Liczba zakładów ubezpieczeń oferujących ubezpieczenia kredytu w latach 2004-2015

Źródło: Opracowanie własne na podstawie danych GUS [2015] i KNF [2015].

O skali korzystania z danego rodzaju ubezpieczeń informuje wolumen składek przypisanych brutto $w$ związku ze sprzedażą tych ubezpieczeń. W zakresie ubezpieczeń kredytu zauważyć można, że począwszy od 2006 roku wolumen tych składek utrzymywał się na relatywnie stałym poziomie (rysunek 2). Spadki, które odnotowano w latach 2008-2010 w stosunku do największej wartości badanego okresu, czyli 2007 roku, należy dopatrywać się częściowo w ograniczonym dostępie do źródeł finansowania przedsiębiorstw takich jak kredyty czy leasing w okresie kryzysu gospodarczego. Należy jednak nadmienić, że z badań przeprowadzonych przez Zawadzką [2009] wynika, iż w dobie spowolnienia gospodarczego, gdy przedsiębiorstwa mają ograniczony dostęp do kapitału, częściej

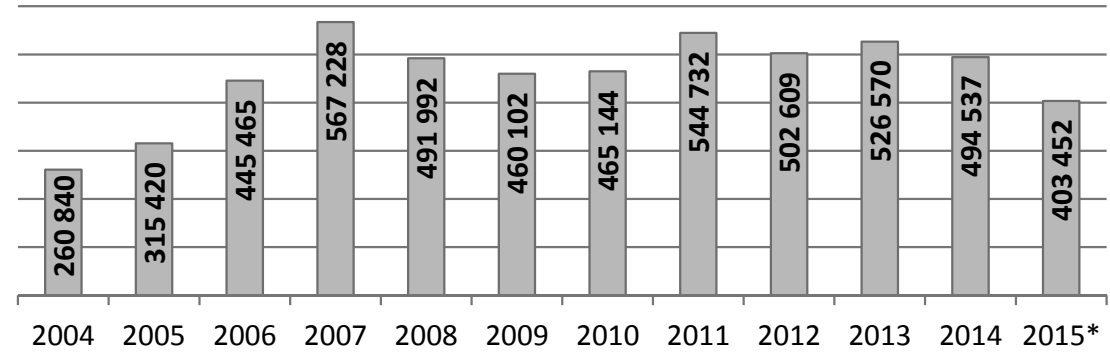

*Dane za lata 2004-2014 pochodzq z publikacji GUS, dane za 2015 rok z publikacji KNF.

RYSUNEK 2. Wartość składki przypisanej brutto z tytułu ubezpieczeń kredytu (grupa 14) w latach 2004-2015 (tys. PLN)

Źródło: Opracowanie własne na podstawie danych GUS [2015] i KNF [2015]. 
wykorzystują w swojej działalności kredyty handlowe. Jednocześnie z badań przeprowadzonych przez Szafraniec-Silutę [2010] wynika, iż w tym okresie zakłady ubezpieczeń odnotowały wzrost wysokości składki przypisanej brutto kredytu kupieckiego, co potwierdza wniosek o ograniczonym dostępie do pozostałych rodzajów kapitału przedsiębiorstw w tym okresie. Biorąc także pod uwagę udział składek przypisanych brutto z tytułu ubezpieczeń kredytu w składce przypisanej ogółem dla działu II (rysunek 3) zauważyć należy, że skala korzystania z ubezpieczeń kredytu wykazuje tendencję malejącą, począwszy od 2008 roku.

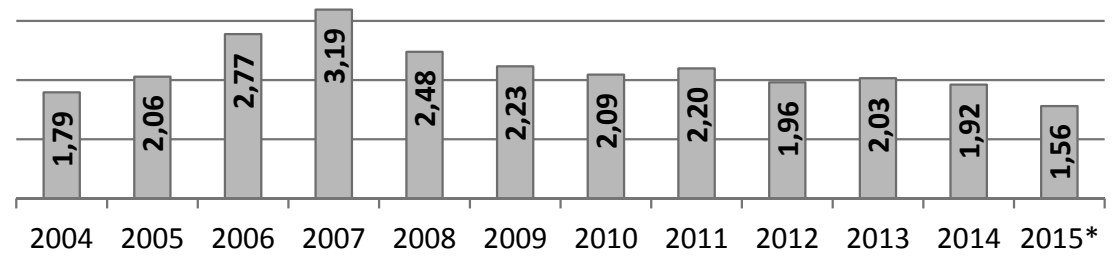

*Dane za lata 2004-2014 pochodzq z publikacji GUS, dane za 2015 rok z publikacji KNF.

RYSUNEK 3. Udział składek przypisanych brutto z tytułu ubezpieczeń kredytu w składce przypisanej brutto ogółem dla działu II ubezpieczeń w latach 2004-2015 (\%)

Źródło: Opracowanie własne na podstawie danych GUS [2015] i KNF [2015].

Warto także zauważyć, że dominującą grupą nabywców ubezpieczeń kredytu są przedsiębiorstwa (rola gospodarstw domowych i pozostałych podmiotów pozostaje marginalna). Potwierdzają to dane zaprezentowane na rysunku 4, z których wynika, że niemal w każdym roku składka przypisana brutto z tytułu ubezpieczeń kredytów zawartych przez przedsiębiorstwa stanowiła ponad 99\% składki przypisanej brutto ubezpieczeń kredytu ogółem. Potwierdza to, że popyt na ubezpieczenia kredytu zgłaszany jest przede wszystkim przez sektor przedsiębiorstw.

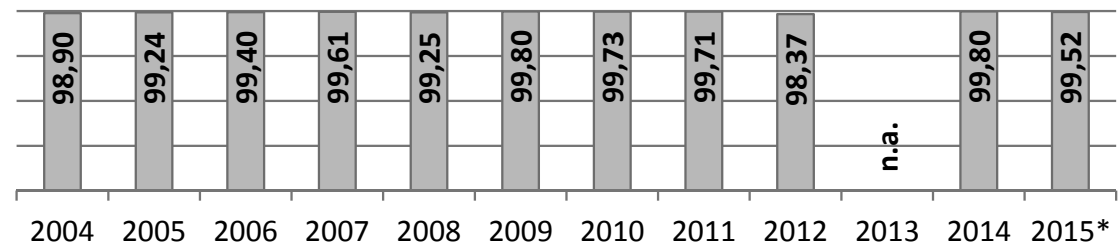

*Dane za lata 2004-2014 pochodzq z publikacji GUS, dane za rok 2015 z publikacji KNF; n.a. - dane niedostępne.

RYSUNEK 4. Udział składki przypisanej brutto z tytułu ubezpieczeń kredytu zawartych przez przedsiębiorstwa w składce przypisanej brutto z tytułu ubezpieczeń kredytu ogółem w latach 2004-2015 (\%)

Źródło: Opracowanie własne na podstawie danych GUS [2015] i KNF [2015]. 
Ocenę ogólną zmian popytu przedsiębiorstw na ubezpieczenia kredytu uzupełnić można o wnioski płynące z analizy udziału składek płaconych przez przedsiębiorstwa z tytułu ubezpieczenia kredytu do całości składek płaconych przez te podmioty za ubezpieczenia działu II. Dane te zaprezentowano na rysunku $5 . \mathrm{Na}$ ich podstawie można stwierdzić, że w latach 2007-2008 udział ten był najwyższy, a następnie sukcesywnie spadał ${ }^{3}$. Zmiany te były spowodowane spadkiem składki przypisanej brutto w ramach ubezpieczeń kredytu, a także wzrostem składki brutto ogółem działu II.

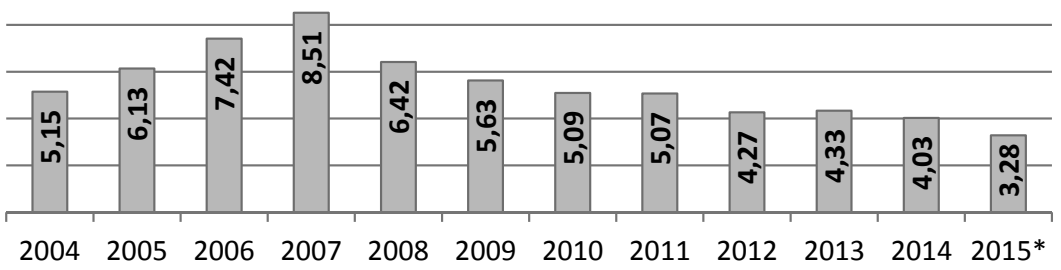

*Dane za lata 2004-2014 pochodzq z publikacji GUS, dane za 2015 rok z publikacji KNF.

RYSUNEK 5. Udział składki przypisanej brutto z tytułu ubezpieczeń kredytu w składce przypisanej brutto ogółem działu II dla sektora przedsiębiorstw latach 2004-2015 (\%)

Źródło: Opracowanie własne na podstawie danych GUS [2015] i KNF [2015].

W obszarze równowagi rynkowej analizie poddano zmiany prostego wskaźnika szkodowości ubezpieczeń kredytu. Dane zaprezentowane na rysunku 6 wskazują, że wskaźnik ten do 2008 roku włącznie utrzymywał się na znacząco

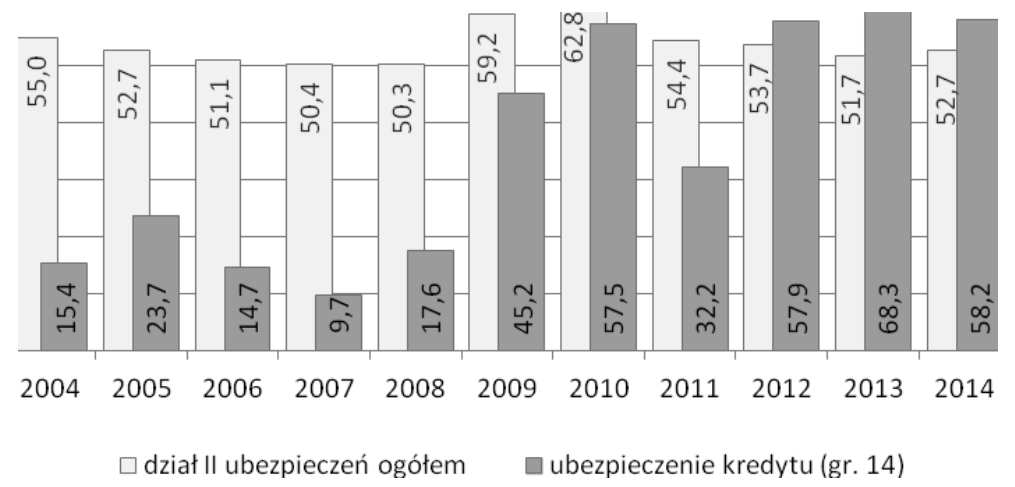

RYSUNEK 6. Wskaźnik szkodowości $(L R)$ ubezpieczeń kredytu na tle wskaźnika szkodowości ubezpieczeń działu II ogółem w latach 2004-2015 (\%)

Źródło: Opracowanie własne na podstawie danych GUS [2015].

${ }^{3}$ Autorka ma świadomość, że ustalenie przyczyn obserwowanego kierunku zmian wymaga przeprowadzenia głębszej analizy przynajmniej w obrębie zmian pozostałych grup ubezpieczeń majątkowych. 
niższym poziomie $w$ porównaniu do lat kolejnych. Można więc stwierdzić, że w latach 2004-2008 sprzedaż ubezpieczeń kredytu była efektywna z perspektywy ubezpieczycieli. Warto zauważyć, że okres ten nakłada się na lata wyższego udziału składek z ubezpieczeń kredytu w składce ogółem dla działu II (na co wskazano wcześniej na rysunku 5). Począwszy od 2009 roku wartości wskaźnika szkodowości dla ubezpieczeń kredytu są porównywalne do wskaźnika szkodowości dla rynku ubezpieczeń działu II ogółem (a w latach 2012-2014 wartości te są nawet wyraźnie wyższe). Z perspektywy nabywców tych ubezpieczeń (głównie przedsiębiorstw) ubezpieczenia kredytu stały się więc bardziej efektywne (w zakresie skali kompensacji szkód).

\section{WNIOSKI}

Zebrane dane pozwoliły stwierdzić, że począwszy od 2004 roku ubezpieczenia kredytu uznać należy za dostępne, przy czym na rynku tym wyraźnie rysują się zmiany w zakresie wolumenu składki przypisanej brutto, jak również szkodowości ubezpieczeń kredytu. Główną grupą nabywców ubezpieczeń kredytu pozostają przedsiębiorstwa.

Przeprowadzone badania mają oczywiście wymiar analizy i oceny pewnych trendów ogólnych. Dostępne dane nie pozwalają niestety analizować głębiej grupy ubezpieczeń kredytu w podziale na jego poszczególne rodzaje. Nie mniej jednak, prezentowane tu wyniki mogą stanowić punkt wyjścia do głębszych analiz tego segmentu rynku ubezpieczeń działu II. W aspekcie podażowym dalszym badaniom poddać można szczegóły oferty ubezpieczeń kredytów. Interesującym kierunkiem badań w zakresie strony popytowej tego zagadnienia jest niewątpliwie kwestia oceny zaobserwowanych zmian popytu na ubezpieczenia kredytu w relacji do zmian popytu na inne ubezpieczenia działu II. W aspekcie równowagi rynkowej również rodzą się pytania o skalę powiązania obserwowanych zmian np. ze zmianami skali upadłości przedsiębiorstw. Przeprowadzane analizy powinny więc być odnoszone do tła ogólnego, jakim są stan gospodarki i sytuacja na poszczególnych jej segmentach ze szczególnym odniesieniem do zmian w okresach spowolnienia gospodarczego, które miało miejsce między innymi w latach 2008-2010, kiedy to strona popytowa ubezpieczeń kredytu zdecydowanie wskazywała na tendencje spadkowe wykorzystywania tej formy zabezpieczeń ryzyka przedsiębiorstw. Sytuacja ta była przede wszystkim skutkiem pogarszania się warunków funkcjonowania przedsiębiorstw, co miało swoje odzwierciedlenie w liczbie upadłości przedsiębiorstw. 


\section{Spis literatury}

BACELLA A. 2015: Kierunki rozwoju ubezpieczeń kredytu kupieckiego w Polsce, Studia Oeconomica Posnaniensia 3, 2, 92-115.

BEDNARCZYK T.H. 2000: Instrumenty wspierania eksportu, PWN, Warszawa.

HANDSCHKE J. 2001: Ubezpieczenia kredytu [w:] T. Sangowski (red.), Ubezpieczenia gospodarcze, Poltext, Warszawa, 238-250.

GORCZYŃSKA M., WIECZOREK-KOSMALA M. 2013: Ubezpieczenia finansowe [w:] M. Iwanicz-Drozdowska (red.), Ubezpieczenia, PWE, Warszawa, 363-381.

GUS 2015: Polski rynek ubezpieczeniowy 2014, Studia i Analizy Statystyczne, Główny Urząd Statystyczny, Warszawa 2015, http://stat.gov.pl/obszary-tematyczne/podmioty-gospodarcze-wyniki-finansowe/przedsiebiorstwa-finansowe/polski-rynek-ubezpieczeniowy-2014,11,4.html\# [dostęp: 15.10.2016].

KNF 2015: Biuletyn roczny. Rynek ubezpieczeń 2015. Komisja Nadzoru Finansowego, http://www.knf.gov.pl/opracowania/rynek_ubezpieczen/Dane_o_rynku/Dane_roczne/dzne_roczne.html [dostęp: 15.10.2016].

KONAT G., KAPRPIŃSKA-MIZIELIŃSKA W., SMUGA T. 2011: Znaczenie ubezpieczeń eksportowych w Polsce w latach 2000-2009, Gospodarka Narodowa 5-6, 21-48.

KUKIEŁKA J., PONIEWIERKA D. 2003: Ubezpieczenia finansowe, Oficyna Wydawnicza Branta, Bydgoszcz-Warszawa.

LISOWSKI J. 2009: Wpływ kryzysu finansowego na rynek ubezpieczeń kredytu kupieckiego, Wiadomości Ubezpieczeniowe 1, 42-66.

LISOWSKI J. 2010: Specyfika gospodarki finansowej ubezpieczycieli kredytu kupieckiego w Polsce, Wydawnictwo UE Poznań, Poznań.

MICHALIK J., SELIGA D. 2003: Ubezpieczenia finansowe [w:] J. Monkiewicz (red.), Podstawy ubezpieczeń. Tom II. Produkty, J. Poltext, Warszawa, 279-312.

OLKIEWICZ A. 2010: Rola instrumentów bankowych i ubezpieczeniowych w ograniczaniu ryzyka handlowego przedsiębiorstw, Zeszyty Naukowe Polityki Europejskiej, Finansów i Marketingu, 4 (53), 287-297.

PAWŁOWSKA-KŁĄB U. 2006: Wybrane aspekty wpływające na decyzje przedsiębiorstwa o zawarciu umowy ubezpieczenia kredytu kupieckiego, Studia i Prace Kolegium Zarządzania i Finansów, 70, 144-154.

STRUPCZEWSKI G. 2013: Ubezpieczenia finansowe [w:] W. Sułkowska (red.), Współczesne ubezpieczenia gospodarcze, Wydawnictwo UE Kraków, Kraków, 165-169.

SZAFRANIEC-SILUTA E. 2010: Znaczenie ubezpieczeń finansowych dla funkcjonowania przedsiębiorstw w Polsce w okresie spowolnienia gospodarczego, Annales Universitatits Marie Curie-Skłodowska Lublin - Polonia, Sectio H 46, 2, 923-935.

Ustawa z dnia 7 lipca 1994 r. o gwarantowanych przez Skarb Państwa ubezpieczeniach kontraktów eksportowych. Dz.U. 1994 nr 86, poz. 398. 
ZAWADZKA D. 2009: Znaczenie ekspansji kredytu kupieckiego dla polityki monetarnej, Zeszyty Naukowe Uniwersytetu Szczecińskiego, 549, Ekonomiczne Problemy Usług, 39, 349-356.

ZNANIECKA K., SZEWIECZEK D., WIECZOREK-KOSMALA M. 2014: Ubezpieczenie jako przedmiot transakcji na rynku ubezpieczeń - aspekt podażowy [w:] K. Znaniecka, M. Wieczorek-Kosmala (red.), Systemy ubezpieczeń CeDeWu, Warszawa, 47-67.

\title{
CREDIT INSURANCE MARKET IN POLAND - ANALYSIS OF THE GENERAL TENDENCIES
}

\begin{abstract}
Credit insurance is one of available methods of protection against the results of market partners insolvency. The purpose of this paper is to analyse the general tendencies observable on Polish credit insurance market in the period of 2004-2015. The study relies on the available market data which were discussed in three dimensions: supply of credit insurance, demand for credit insurance (in particular in corporate customers' sector) and market equilibrium. The study has shown that the supply of credit insurance was relatively stable over the analysed period, and the leading group of purchasers were corporate customers. Since 2009 , the market equilibrium has changed, due to the increasing burden of claims paid, relative to gross premiums written.
\end{abstract}

Key words: credit insurance, market for credit insurance, companies 